\title{
PENGEMBANGAN INDUSTRI PENGOLAHAN IKAN DITINJAU DARI PRODUKSI HASIL TANGKAPAN DI PPN PALABUHANRATU
}

\author{
Fish Processing Industry Development Viewed From Catch Production in \\ Territorial Fishing Port of Palabuhanratu \\ Oleh: \\ Ernani Lubis ${ }^{*}$ dan Sumiati ${ }^{2}$ \\ ${ }^{1}$ Departemen Pemanfaatan Sumber Daya Perikanan, FPIK, IPB \\ 2 Alumni Departemen Pemanfaatan Sumber Daya Perikanan, FPIK, IPB \\ *Korespondensi: ernani_ipb@yahoo.com
}

Diterima: 4 Mei 2010; Disetujui: 20 April 2011

\begin{abstract}
In fact, fish processing industry is very importance to support development a fishing port. It is the same with the case of territorial fishing port (PPN) of Palabuhanratu. So that a research to determine the condition of fish catch production that was able to support the development of fish processing industry, need to be done. A case study on the underdeveloped of fish processing industry in PPN Palabuhanratu was done. Data analysis using descriptive numerical projection of the catch by estimating the need for the development of fish processing industry. Processing type that exist in PPN Palabuhanratu and nowadays are the processing on fish freezing, fish boiling, fish salting, crisp chips, meatball fish and abon fish. Based on the result of projection, the best fish production prospective as raw material for fish processing industry are skipjack tunas, eastern little tuna, tunas, hairtails, shark, ponyfish, ray, Indo-Pacific marlin, scads and wolf herring. A preceding ten year period of 2008-2017, the production of skipjack tunas, eastern little tuna, tunas, ponyfish, Indo-Pacific marlin, scads and wolf herring tend to increase, while the others will decrease. The development of other types of processing industries can be done for freezing, canning, fillet, loin, surimi and nuggets fish.
\end{abstract}

Key words: fish catch production, fish processing industry, PPN Palabuhanratu

\begin{abstract}
ABSTRAK
Industri pengolahan ikan sangat penting keberadaannya untuk menunjang pengembangan suatu pelabuhan perikanan. Demikian halnya yang terjadi di Pelabuhan Perikanan Nusantara (PPN) Palabuhanratu sehingga penelitian untuk mengetahui produksi hasil tangkapan yang dapat menunjang pengembangan industri pengolahan, perlu dilakukan. Metode penelitian yang digunakan adalah studi kasus terhadap belum berkembangnya industri pengolahan ikan di PPN Palabuhanratu. Analisis data menggunakan deskriptif numerik untuk proyeksi hasil tangkapan dengan mengestimasi kebutuhan terhadap pengembangan industri pengolahan ikan. Jenis pengolahan yang ada di PPN Palabuhanratu dan sekitarnya pada saat ini adalah pembekuan, pemindangan, pengasinan, kerupuk, abon dan bakso ikan. Berdasarkan hasil proyeksi, jenis ikan yang produksinya memiliki kontinuitas terbaik dan berpeluang menjadi bahan baku industri pengolahan adalah ikan cakalang, tongkol, tuna, layur, cucut, peperek, pari, jangilus, layaran dan pedang-pedang. Periode sepuluh tahun ke depan (2008-2017), jenis ikan cakalang, tongkol, tuna, peperek, jangilus, layaran dan pedang-pedang jumlahnya cenderung meningkat, sedangkan yang lainnya menurun. Pengembangan jenis industri olahan lainnya dapat berupa pengalengan, fillet, loin, surimi dan nugget ikan.
\end{abstract}

Kata kunci: Produksi hasil tangkapan, industri pengolahan ikan, PPN Palabuhanratu 


\section{PENDAHULUAN}

\section{Latar Belakang}

Produksi hasil tangkapan yang didaratkan di pelabuhan perikanan (PP) sering berlimpah pada musim puncak ikan sehingga sering merugikan nelayan karena turunnya nilai jual. Beberapa kasus terjadi nelayan sampai membuang hasil tangkapannya ke laut ketika musim puncak karena kurangnya fasilitas di pelabuhan perikanan yang dapat menampung kelebihan ikan baik itu cold storage maupun usaha industri pengolahan ikan. Pelabuhan perikanan khususnya tipe samudera dan nusantara hendaknya dapat merangsang timbulnya industri perikanan (Permen Kelautan dan Perikanan Nomor Per.16/Men/2006 tentang Pelabuhan Perikanan yang diacu oleh DKP 2008) sehingga perlu menyediakan bahan bakunya.

Perusahaan industri pengolahan ikan yang berlokasi di suatu PP atau sekitarnya umumnya menggunakan sebagian atau keseluruhan bahan bakunya dari PP tersebut. Ketersediaan bahan baku secara kontinyu diperlukan agar pengusaha mendapatkan kepastian dalam usahanya. Bahan baku yang ada di Palabuhanratu masih belum mencukupi yang diindikasikan dengan masih didatangkannya sebagian bahan baku dari daerah lain khususnya dari Jakarta. Dalam rangka pengembangan industri olahan di Palabuhanratu baik volume maupun jenis olahannya maka perlu kiranya dilakukan proyeksi ke depan terhadap produksi hasil tangkapan yang didaratkan.

Pantai Selatan Jawa Barat, merupakan salah satu daerah potensi perikanan yang perairannya merupakan daerah penangkapan utama bagi nelayan karena berhubungan langsung dengan Samudera Hindia. Salah satu PP sebagai tempat pendaratan hasil tangkapan adalah Pelabuhan Perikanan Nusantara (PPN) Palabuhanratu yang dibangun dengan berbagai fasilitas dan didukung oleh akses pemasaran yang dekat dengan Jakarta dan Bandung. Namun sampai saat ini belum ada industri pengolahan di dalam melainkan berada di luar lokasi PP dengan skala rumah tangga, diperkirakan karena masih terbatasnya produksi yang ada.

Penelitian ini bertujuan untuk mengetahui kondisi produksi hasil tangkapan yang didaratkan dan proyeksinya ke depan dalam rencana pengembangan industri pengolahan ikan di PPN Palabuhanratu. Statistik perikanan PPN Palabuhanratu tahun 2005 menunjukkan dalam tiga belas tahun operasional (1993-2005) atau sejak diresmikannya PPN Palabuhanratu pada tanggal 18 Februari 1993, perkembangan produksi perikanan pada periode 1996-2005 mengalami peningkatan rata-rata $23,70 \%$ per ta- hun. Produksi perikanan tahun 2005 mengalami peningkatan sebesar $94,76 \%$ dibandingkan tahun 2004 atau terjadi peningkatan produksi sebesar $6.068,92$ ton. Peningkatan volume produksi perikanan ini diikuti juga oleh kenaikan nilainya sebesar $109,67 \%$ atau $\operatorname{Rp} 34.619 .207$. 469,00 (PPN Palabuhanratu 2008).

Penelitian-penelitian terdahulu yang telah dilakukan di PPN Palabuhanratu antara lain mengkaji kebijakan pemerintah dalam pembangunan pelabuhan, sistem informasi manajemen, analisis hasil tangkapan dan pengendalian mutunya.

\section{METODOLOGI}

Penelitian dilakukan selama bulan MeiJuni 2006 di Pelabuhan Perikanan Nusantara Palabuhanratu, Sukabumi, Jawa Barat dimana ditemukan kasus belum berkembangnya industri pengolahan ikan.

Data primer dikumpulkan melalui wawancara dan pengisian kuisioner kepada pihak pengelola PPN Palabuhanratu, Koperasi Unit Desa (KUD) sebagai pengelola Tempat Pelelangan Ikan (TPI), pihak industri pengolahan ikan, nelayan dan pedagang ikan. Jumlah responden ditentukan secara purposive yang dapat mewakili tujuan penelitian. Data sekunder diambil dari PPN Palabuhanratu, Dinas Perikanan Propinsi Jawa Barat dan Dinas Perikanan Kabupaten Sukabumi.

Analisis data dilakukan secara deskriptifnumerik melalui penyajian grafik setelah dilakukan identifikasi industri pengolahan ikan, produksi hasil tangkapan dan proyeksinya. Analisis pertumbuhan produksi hasil tangkapan PPN Palabuhanratu selama 10 tahun terakhir (19962005) dilakukan untuk mengetahui kemungkinan ketersediaan bahan baku industri, baik jenis maupun volumenya. Selanjutnya dilakukan proyeksi produksi hasil tangkapan yang didaratkan di pelabuhan tersebut selama 10 tahun ke depan melalui metode peramalan model dekomposisi multiaplikatif, untuk analisis pengembangan industri olahan. Analisis terhadap asal bahan baku dilakukan secara deskriptif apakah ikan-ikan yang dapat digunakan sebagai bahan baku olahan cukup tersedia dari PPN Palabuhanratu saja dan apakah jenis-jenis ikan dominan selalu ada sepanjang tahun dalam jumlah yang cukup sesuai dengan kebutuhan dan pengembangan industri olahan.

Data hasil tangkapan selama 10 tahun terakhir dijadikan salah satu pendekatan jangka menengah dengan memperhitungkan pengaruh faktor musim, trend dan siklus. Faktor musiman terkait dengan fluktuasi periodik yang relatif konstan dalam jangka waktu tertentu atau ber- 
ulang pada interval waktu yang tetap sepanjang tahun. Trend menunjukkan perilaku data dalam jangka panjang yang meningkat, menurun atau tidak berubah sama sekali. Siklus menggambarkan naik-turunnya ekonomi atau industri tertentu. Berbeda halnya dengan musiman, siklik bersifat tidak tetap, bervariasi dari satu ke siklus lain. Model persamaannya :

$Y t=l t \times T t \times C t \times E t$.

dimana:

Yt = Nilai deret waktu (data aktual) pada periode $t$

It $=$ Indeks musiman pada periode $\mathrm{t}$

$\mathrm{Tt}=$ Komponen trend pada periode $\mathrm{t}$

$\mathrm{Ct}=$ Komponen siklik pada periode $\mathrm{t}$

$\mathrm{Et}=$ Komponen galat pada periode $\mathrm{t}$

Langkah-langkah penyelesaian dengan model dekomposisi multiplikatif :

(1) Dari data aktual Yt, tentukan rata-rata bergerak (moving average) 12 bulan. Tujuan dari tahap ini adalah untuk memperoleh dugaan dari trend $(\mathrm{Tt})$ dan siklik $(\mathrm{Ct})$.

$M t=T t \times C t$.

(2) Untuk memperoleh pengaruh musiman (It), membagi persamaan (1) dan persamaan (2)

$(Y t / M t)=l t \times E t$

(3) Identifikasi pengaruh trend $(\mathrm{Tt})$ yang sesuai dengan perilaku data dengan metode kuadrat terkecil seperti halnya pada model regresi. Model penduga trend:

$T t=a+b t$

dimana:

$\mathrm{Tt}=$ Kecendrungan (trend) pada periode $\mathrm{t}$

$\mathrm{t} \quad=$ Indeks waktu

$\mathrm{a}, \mathrm{b}=$ Nilai penduga parameter model

Dengan menggunakan metode kuadrat terkecil, nilai-nilai a dan b dapat ditentukan:

$$
\begin{aligned}
b & =\left(n \sum t Y-\Sigma t \Sigma Y\right) / n \sum t^{2}-\left(\sum t\right)^{2} \\
a & =(\Sigma Y / n)-b(\Sigma t / n) \ldots \ldots \ldots \ldots \ldots \ldots \ldots \ldots
\end{aligned}
$$

(4) Komponen siklik (Ct) diperoleh melalui pembagian persamaan (2) dengan $\mathrm{Tt}$

$(M t / T t)=C t$

(5) Untuk keperluan peramalan, digunakan ketiga komponen (It, Tt, Ct)

$\hat{Y}=l t \times T t \times C t$

(6) Rasio antara data aktual (Yt) dengan nilai yang diduga $(\hat{\mathrm{Y}} \mathrm{t})$ merupakan pengaruh galat (Et)

$E t=V t / \hat{Y}$

\section{HASIL DAN PEMBAHASAN}

\section{Kondisi produksi hasil tangkapan didarat- kan di PPN Palabuhanratu.}

Produksi hasil tangkapan pada periode 1996-2005 mengalami peningkatan rata-rata $23,70 \%$ per tahun. Hal ini dapat diartikan bahwa potensi sumber daya ikan tersedia di perairan Selatan Jawa masih cukup besar.

Berdasarkan data statistik PPN Palabuhanratu tahun 2005 terdapat 56 jenis ikan yang didaratkan di PPN Palabuhanratu. Jenis ikan dominan yang didaratkan di PPN Palabuhanratu adalah tuna (Thunnus sp.), cakalang (Katsuwonus pelamis), tongkol (Auxis thazard), baronang (Siganus spp.), cucut (Carcharhinus sp.), tembang (Sardinella sp.), layang (Decaptherus russeli), layur (Trichiurus sp.), peperek (Leignathus sp.) dan pedang-pedang (Xiphias gladius). Hal ini sesuai dengan ketersediaan sumber daya ikan yang ada di Teluk Palabuhanratu dan alat tangkap yang digunakan. Unit penangkapan yang terdapat di PPN Palabuhanratu adalah pancing, gillnet, bagan, payang, rawai, purse seine, trammel net, rampus dan tuna longline. Ikan tuna dan cakalang merupakan jenis hasil tangkapan terbesar di PPN Palabuhanratu, masing-masing mencapai $28,97 \%$ dan $28,19 \%$. Tingginya volume produksi tersebut terkait dengan dominasi payang dan tuna longline yang beroperasi.

Hasil tangkapan yang didaratkan di PPN Palabuhanratu bersumber langsung dari laut dan dari daerah lain melalui jalur darat. Hasil tangkapan yang didaratkan langsung dari laut antara lain cakalang, tongkol, tuna, baronang, cucut, tembang, layang, layur, peperek dan pedang-pedang. Produksi hasil tangkapan dari laut pada tahun 2005 jumlahnya hanya 12.473,01 ton, sedangkan yang melalui jalur darat jumlahnya sangat besar, yaitu mencapai $5.872,57$ ton atau $47,08 \%$. Produksi PPN Palabuhanratu yang didistribusikan dalam bentuk segar adalah 3.397,44 ton dan yang didistribusikan sebagai bahan baku olahan di Palabuhanratu 3.203,09 ton. Volume bahan baku olahan tersebut digunakan untuk pengasinan $1.452,59$ ton, pemindangan $1.747,19$ ton dan produk ikan olahan lainnya 3,32 ton.

Ikan yang masuk melalui jalur darat ke PPN Palabuhanratu berasal dari beberapa tempat terutama daerah Jakarta sebanyak $4.538 .727 \mathrm{~kg}$ (77,29\%). Tempat-tempat lain yang berada di Teluk Palabuhanratu juga cukup banyak mensuplai ikan ke PPN Palabuhanratu antara lain Ujung Genteng dan Cisolok. Hal ini terkait akses yang relatif mudah sehingga biaya yang dikeluarkan untuk mendatangkan ikan relatif kecil selain juga mutu ikan rata-rata masih 
segar karena waktu distribusinya relatif tidak terlalu lama.

Ikan yang didatangkan dari luar Palabuhanratu diantaranya cakalang, eteman, cucut, pari, layaran dan layur. Menurut Mahyuddin (2007), terdapat suplai ikan seperti peperek, tembang dan tongkol dari daerah-daerah Pantura Jawa. Hal ini dilakukan karena terkait harga dan mutu ikan yang lebih baik ditambah suplai yang ditawarkan dalam jumlah besar sehingga biaya transportasi per kilogramnya relatif kecil. Ikan yang didatangkan melalui jalur darat tersebut rata-rata digunakan sebagai bahan baku industri pengolahan pemindangan di Palabuhanratu. Harga ikan-ikan tersebut termasuk relatif lebih murah dikarenakan mutu ikannya rendah, khususnya yang berasal dari Jakarta merupakan ikan-ikan yang sudah lama berada di cold storage. Kondisi mutu tersebut tidak menjadi permasalahan bagi para pengolah pemindangan yang biasanya kurang memperhatikan mutu ikan dan modal yang masih lemah. Padahal menurut Yunindari et al. (2006) bahwa suatu perusahaan harus sangat memperhatikan mutu produk yang dihasikan agar sesuai dengan standar mutu yaitu Hazard analysis and Critical Control Point (HACCP) khususnya untuk produk ekspor.

\section{Proyeksi produksi hasil tangkapan seba- gai kebutuhan bahan baku}

Salah satu hal yang penting dalam industri pengolahan ikan adalah penyediaan bahan baku ikan. Ketersediaan bahan baku akan menentukan kelangsungan usaha bagi industri pengolahan ikan, terutama industri yang berada di kawasan PPN Palabuhanratu.

Saat ini di PPN Palabuhanratu hanya terdapat satu unit industri pengolahan yaitu PT. AGB Palabuhanratu yang bergerak pada pembekuan khusus ikan layur. Pada awal pendirian, perusahaan ini diorientasikan untuk pembekuan berbagai hasil tangkapan yang ada di PPN Palabuhanratu, tetapi karena terdapat kesulitan dalam menstandarkan produk berkualitas ekspor serta kendala musim ikan yang tidak menentu, akhirnya perusahaan mengalihkan orientasinya khusus pada industri pembekuan ikan layur, dimana produksinya periode 2005-2006 adalah 212,21 ton, 99\% diantaranya diekspor. Tujuan ekspornya sampai saat ini adalah Korea dan Cina, sisanya dipasarkan secara lokal antara lain untuk konsumen restoran di Jakarta. Perusahaan ini juga memperoleh sebagian kecil bahan bakunya dari luar PPN diantaranya Cisolok, Ujung Genteng dan Binuangeun.

Berdasarkan jenis-jenis ikan dominan yang didaratkan di PPN Palabuhanratu, maka yang memiliki kontinuitas terbaik untuk dijadikan bahan baku olahan adalah cakalang, tuna, tongkol, peperek, layur, pedang-pedang, cucut, layaran, jangilus dan pari. Kontinuitas tersebut terlihat dari jenis-jenis ikan yang didaratkan setiap bulannya terutama pada tahun 2005. Ikan tuna memiliki rata-rata produksi per bulan terbesar pada tahun 2005 yaitu mencapai 159,36 ton, sedangkan yang rata-rata produksinya terendah (1,62 ton) adalah ikan pari.

Jenis-jenis ikan dominan yang diproyeksikan dan berpeluang menjadi bahan baku industri pengolahan meliputi ikan tongkol, cakalang, tuna, layur, cucut, peperek, pari, jangilus, layaran dan pedang-pedang. Jenis-jenis ikan tersebut rata-rata termasuk jenis ikan ekonomis tinggi serta merupakan bahan baku utama industri pengolahan modern seperti pembekuan dan pengalengan, terutama cakalang dan tuna.

Gambar 1, 2, 3, 6, 8, 9, dan 10 masingmasing menunjukkan hasil proyeksi produksi jenis ikan cakalang, tongkol, tuna, peperek, jangilus, layaran dan pedang-pedang mengalami peningkatan sedangkan jenis ikan layur, cucut dan pari mengalami penurunan setiap tahunnya. Meningkatnya volume ikan tersebut akibat adanya peningkatan unit penangkapan yang digunakan. Gambar 1-10 menunjukkan grafik perkembangan proyeksi produksi 10 jenis ikan dominan berdasarkan data tahun 1996-2005.

Ikan cakalang merupakan jenis ikan pelagis yang ditangkap oleh alat tangkap gillnet, pancing tonda dan payang. Produksi ikan cakalang di PPN Palabuhanratu rata-rata mencapai 1.008,12 ton per tahun. Pada tahun 2005 alat tangkap yang dominan menangkap cakalang adalah payang yang mencapai $90,20 \%$ dari total $1.860,68$ ton ikan cakalang didaratkan di PPN Palabuhanratu. Pemasarannya meliputi Palabuhanratu, Sukabumi, Cianjur, Bogor dan Jakarta. Produksi pada tahun 2008 mencapai $1.137,8$ ton dan proyeksi sampai tahun 2017 adalah $3.928,8$ ton.

Ikan tongkol merupakan jenis ikan pelagis yang biasanya bergerombol. Ikan tongkol di PPN Palabuhanratu ditangkap oleh alat tangkap payang, gillnet, bagan dan pancing tonda. Produksi ikan tongkol di PPN Palabuhanratu rata-rata mencapai 558,20 ton per tahun. Hal ini cukup beralasan karena payang yang digunakan untuk menangkap ikan tongkol cukup produktif, efektif dan jumlahnya dominan. Pada tahun 2005, ikan tongkol yang tertangkap oleh payang adalah $91,09 \%$ dari 626,25 ton ikan tongkol yang didaratkan di PPN Palabuhanratu. Pemasarannya adalah Palabuhanratu, Sukabumi, Jakarta, Bandung, Bogor, Cianjur. Hasil proyeksinya pada tahun 2017 mencapai 1.422 ton. 


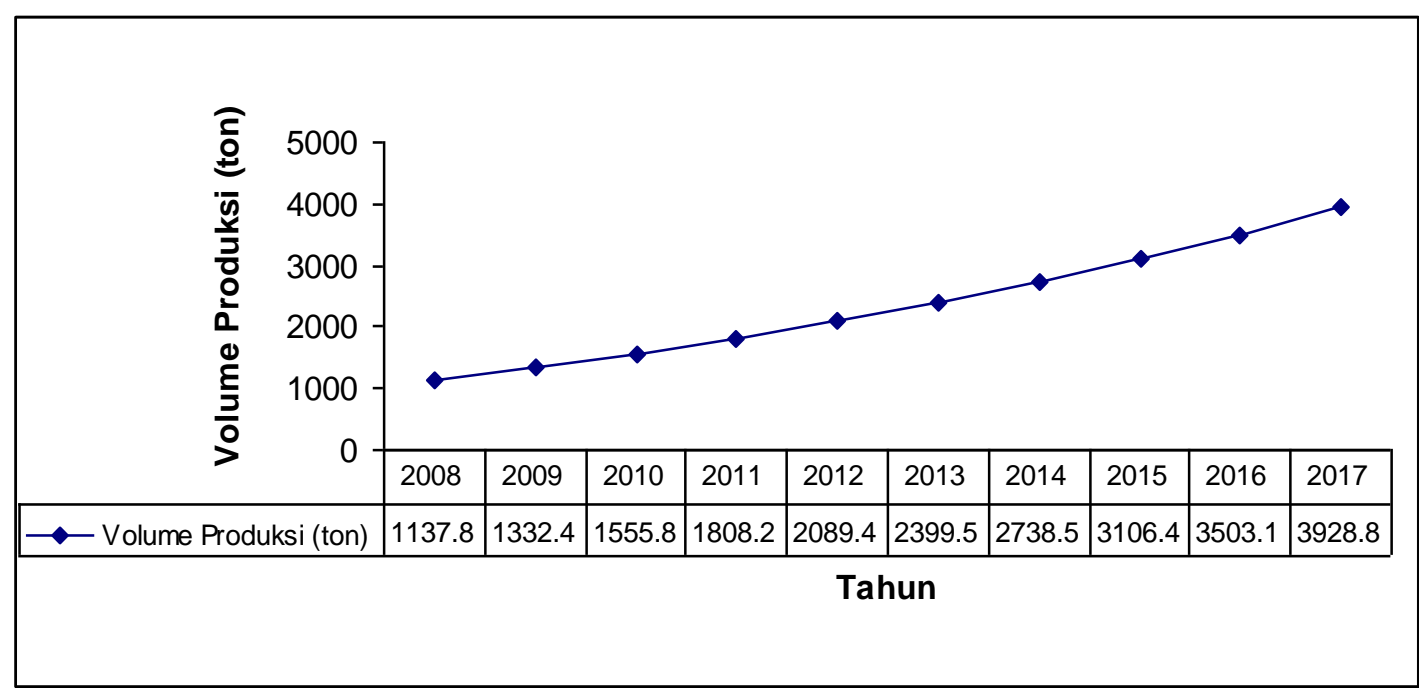

Gambar 1 Proyeksi ikan cakalang.

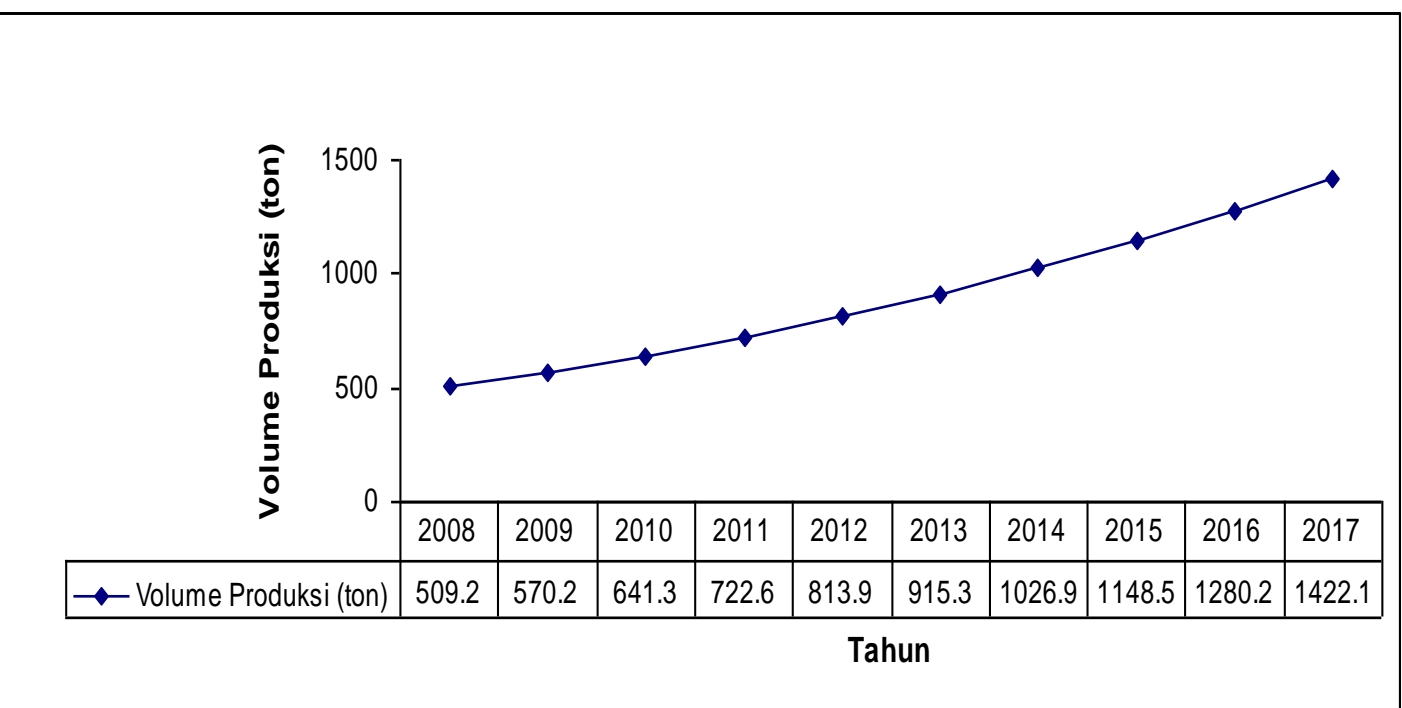

Gambar 2 Proyeksi ikan tongkol.

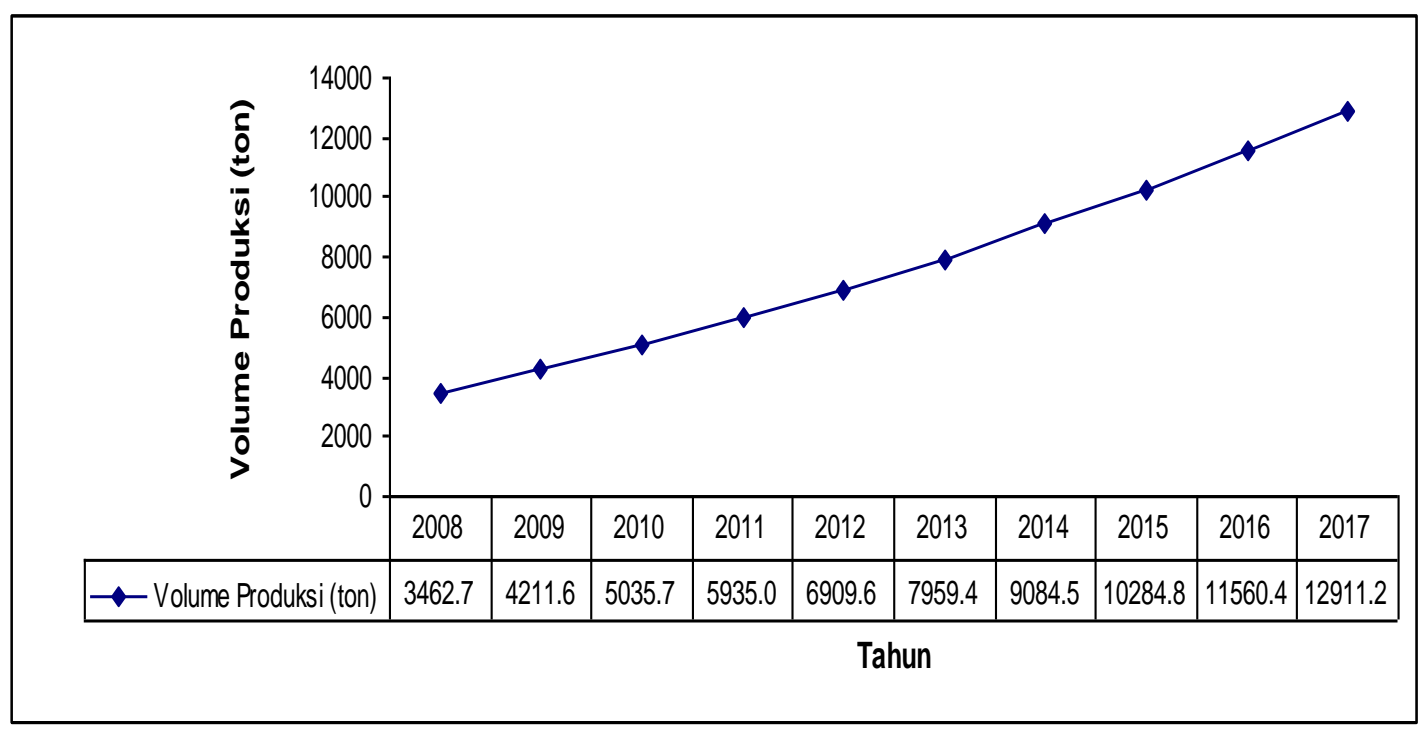

Gambar 3 Proyeksi ikan tuna. 


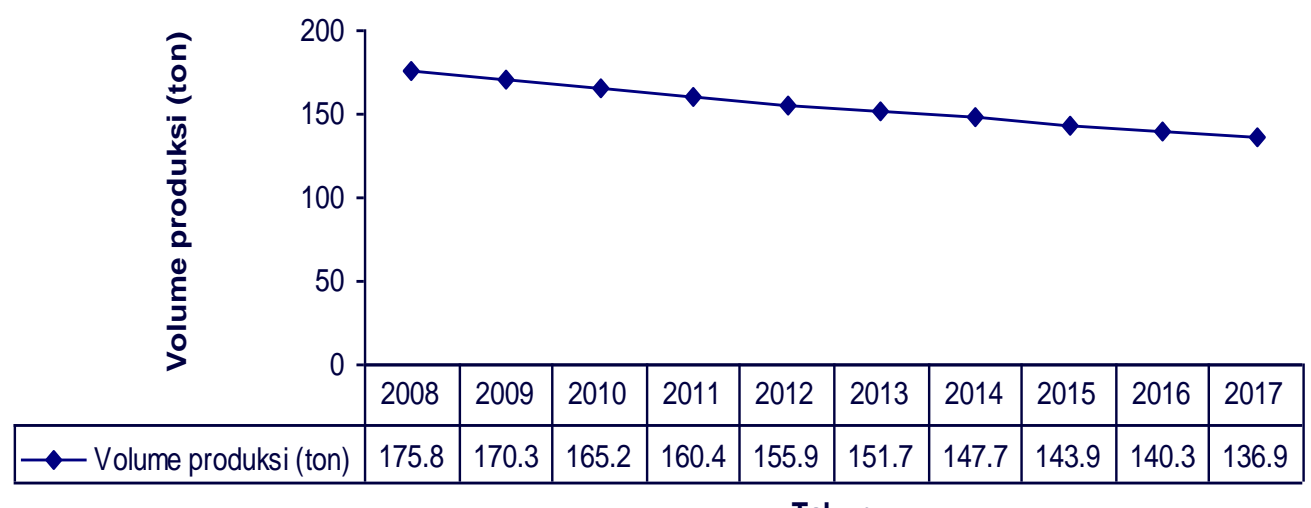

Tahun

Gambar 4 Proyeksi ikan layur.

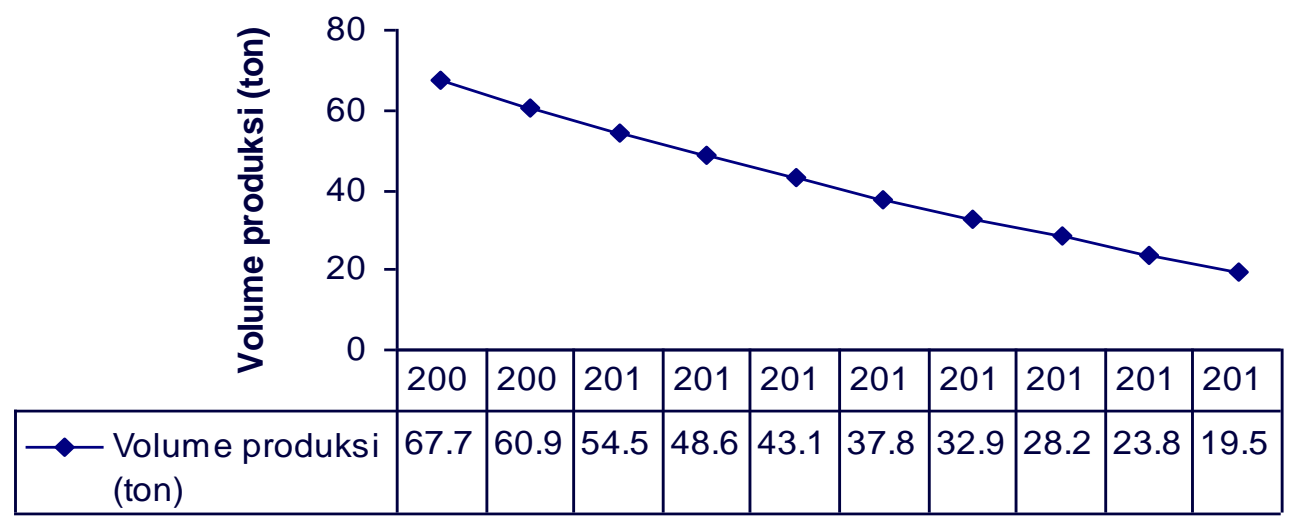

Tahun

Gambar 5 Proyeksi ikan cucut.

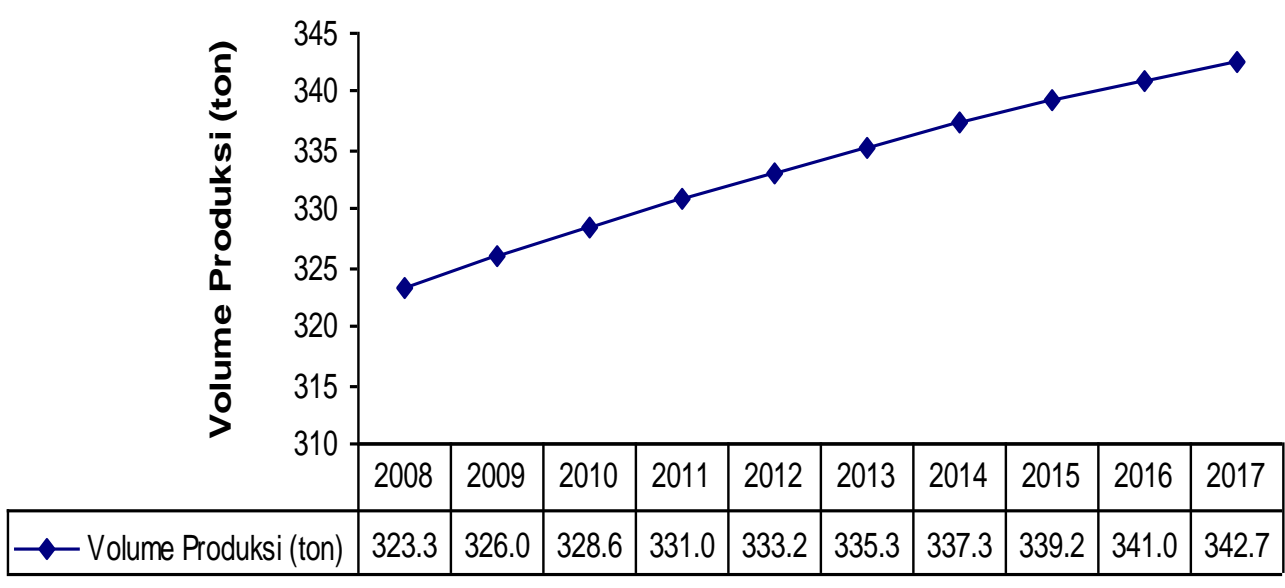

Tahun

Gambar 6 Proyeksi ikan peperek. 


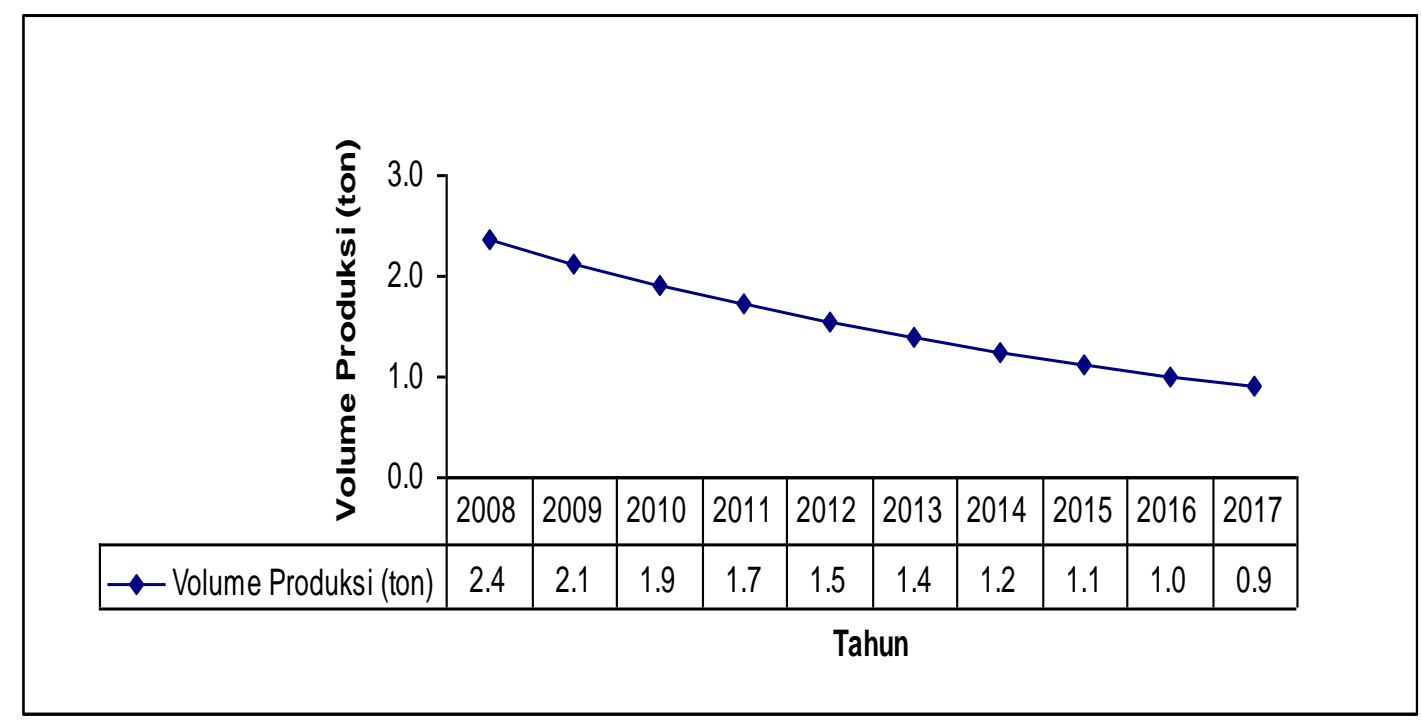

Gambar 7 Proyeksi ikan pari.

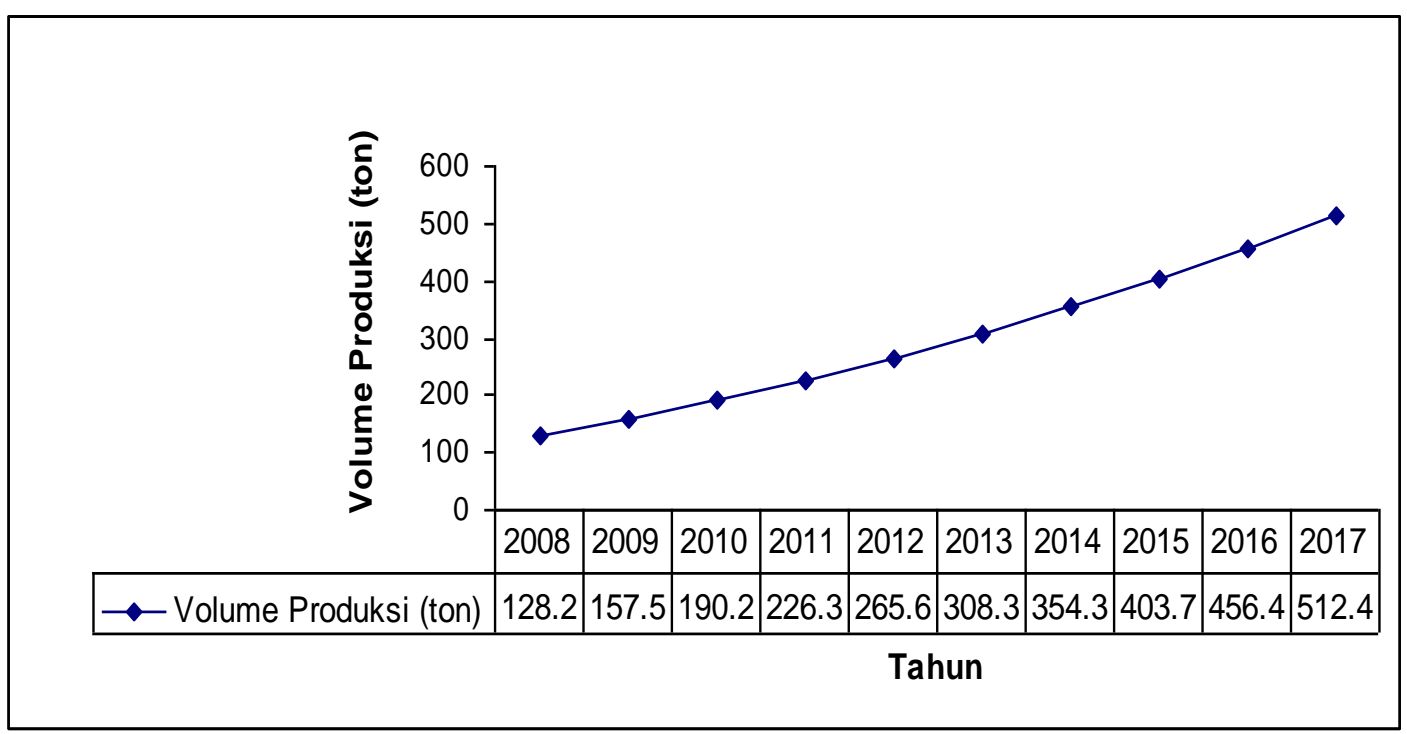

Gambar 8 Proyeksi ikan jangilus.

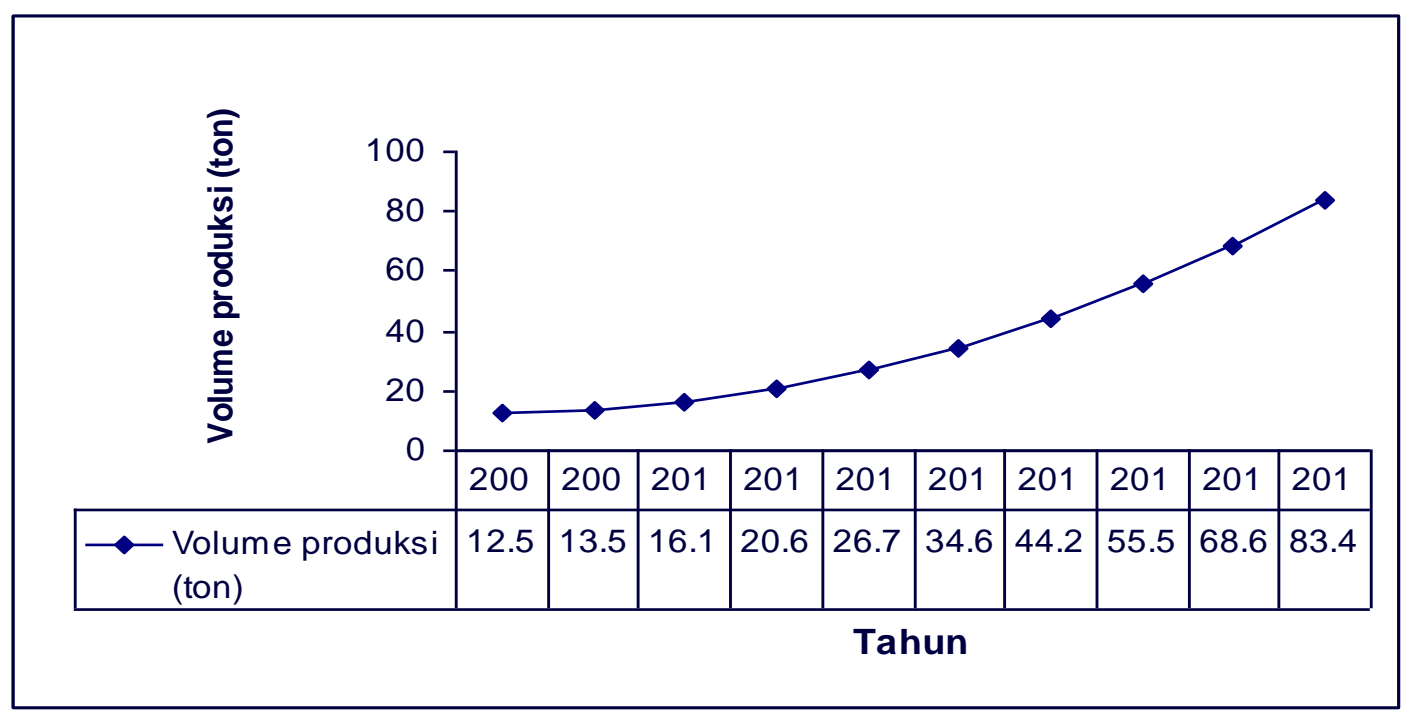

Gambar 9 Proyeksi ikan layaran. 


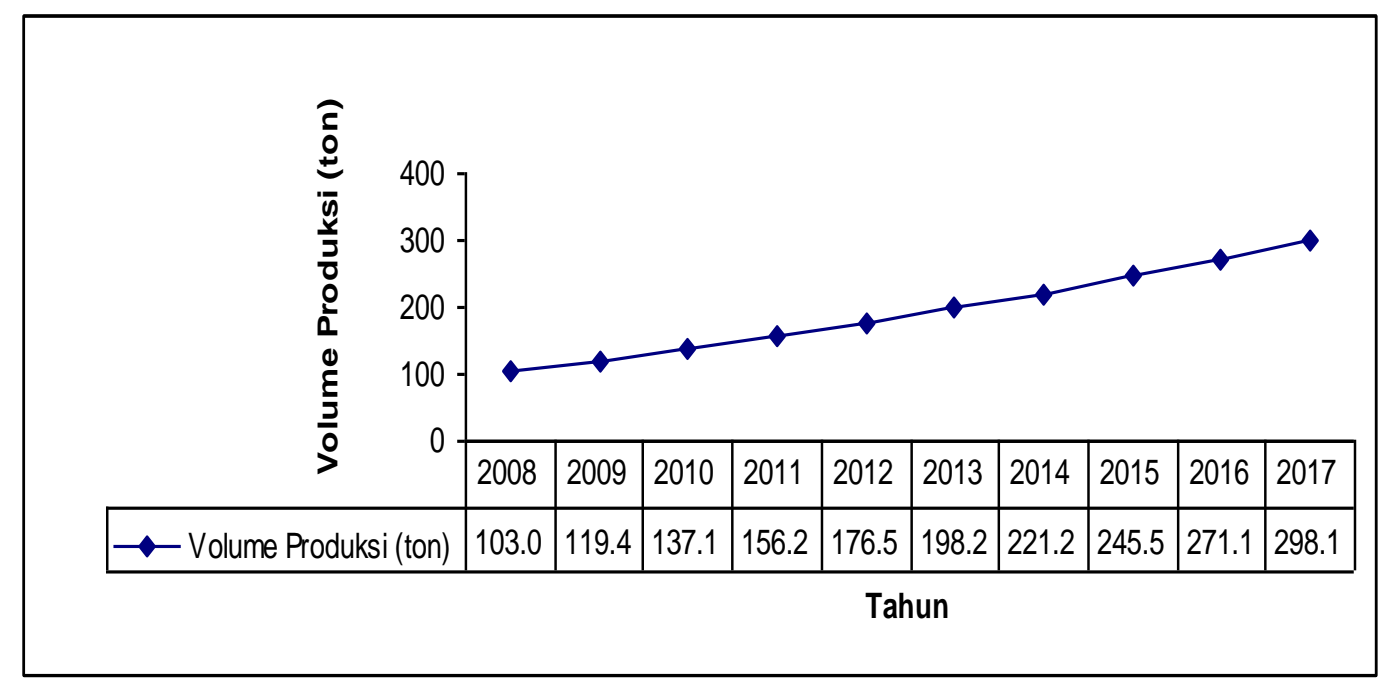

Gambar 10 Proyeksi ikan pedang-pedang.

Ikan layur merupakan jenis ikan yang cenderung berada di dasar dan bergerombol. Ikan layur di Palabuhanratu ditangkap oleh alat tangkap pancing ulur, payang dan trammel net. Produksinya rata-rata mencapai 181,16 ton per tahun. Pada tahun 2005 alat tangkap yang dominan menangkap ikan layur adalah pancing ulur atau mencapai $87,45 \%$ dari 188,99 ton ikan layur didaratkan di PPN Palabuhanratu. Harganya berkisar antara $\mathrm{Rp} 4.931,00$ sampai Rp 12.000,00/kg dan dipasarkan sekitar Palabuhanratu, Sukabumi, Bogor dan Cianjur serta Ja-karta untuk selanjutnya diekspor ke Korea dan Cina dalam bentuk beku. Produksi ikan layur di PPN Palabuhanratu semakin berkurang diban-ding tahun-tahun sebelumnya sehingga proyeksinya pada tahun 2017 hanya mencapai 136,9 ton.

Ikan cucut merupakan jenis ikan demersal yang ditangkap oleh gillnet. Produksinya di PPN Palabuhanratu rata-rata mencapai 167,50 ton per tahun. Harganya antara Rp 5.659,00Rp 11.202,00/kg, dipasarkan di sekitar Kota Palabuhanratu dan Sukabumi. Ikan cucut pada saat ini digunakan sebagai bahan baku industri pengolahan pemindangan, pengasinan dan kerupuk ikan. Produksi ikan cucut di PPN Palabuhanratu cenderung mengalami penurunan, sampai tahun 2017 hanya mencapai 19,5 ton. Ikan peperek merupakan jenis ikan pelagis, di Palabuhanratu ditangkap oleh alat tangkap seperti bagan, gillnet, payang dan purse seine. Produksi ikan peperek di PPN Palabuhanratu rata-rata mencapai 218,65 ton per tahun. Produksi peperek yang berasal dari alat tangkap bagan $(54,47 \%)$ dan payang $(45,28 \%)$ digunakan sebagai bahan baku industri pengolahan pemindangan dan pengasinan. Produksi ikan peperek terus mengalami kenaikan dan proyeksinya sampai pada tahun 2017 mencapai 342,7 ton.
Ikan pari merupakan jenis ikan demersal yang ditangkap oleh alat tangkap gillnet. Produksi ikan pari di PPN Palabuhanratu rata-rata mencapai 31,65 ton per tahun. dan digunakan sebagai bahan baku industri pengasinan dan kerupuk ikan. Produksi PPN Palabuhanratu terhadap ikan pari terus mengalami penurunan dan sampai tahun 2017 hanya mencapai 0,9 ton. Sebaliknya ikan jangilus, layaran dan pedang-pedang yang termasuk jenis ikan pelagis terus mengalami peningkatan dan pada tahun 2017 masing-masing mencapai 512,4 ton, 83,4 ton dan 298,1 ton.

\section{Pembahasan}

Kontinuitas bahan baku ikan diperlukan untuk menjamin keberlanjutan usaha olahan. Seperti juga menurut Cabanne (1978) bahwa kekontinuan bahan baku ikan adalah merupakan faktor penting bagi rentabilitas perusahaan pengolahan ikan. Dikatakannya bahwa dengan menurunnya potensi sumber daya ikan di Laut Atlantik, perusahaan penangkapan yang mensuplai bahan baku ikan di wilayah Bretagne sampai menangkap ikan ke Perairan Golf de Guinée. Kontinuitas bahan baku pada bidang perikanan khususnya perikanan tangkap dipengaruhi oleh faktor alam diantaranya cuaca dan musim. Kontinuitas stok bahan baku diperlukan untuk mengantisipasi kekurangan suplai bahan baku pada saat tidak musim ikan. Hal tersebut sangat penting karena berpengaruh kepada besarnya biaya tetap yang harus dikeluarkan apabila proses produksi tidak berjalan.

Perairan Selatan Jawa yang masih mempunyai potensi sumber daya ikan cukup tinggi di bandingkan dengan Perairan di Utara Jawa berpeluang bagi kapal-kapal untuk lebih meningkatkan jumlah hasil tangkapannya. PPN Palabuhanratu yang berada di Selatan Jawa 
mempunyai produksi hasil tangkapan kontinyu khususnya terhadap 10 jenis ikan yang dijadikan bahan baku industri pengolahan dan memiliki kontinuitas penuh 12 bulan yaitu cakalang, tongkol, tuna, layur, cucut, peperek, pari, jangilus, layaran dan pedang-pedang.

Tuna dan cakalang merupakan jenis ikan yang memiliki potensi terbesar sebagai bahan baku industri pengolahan ikan dikarenakan memiliki nilai ekonomis yang tinggi dan merupakan komoditas unggulan untuk ekspor. Jenis tuna merupakan salah satu jenis ikan yang belum dimanfaatkan sebagai bahan baku industri pengolahan ikan di PPN Palabuhanratu, seharusnya produksinya yang cukup besar dapat memberikan peluang besar masuknya investor sebagai pemeran utama dalam industri pengolahan ikan tuna. PPN Palabuhanratu adalah pelabuhan perikanan yang berlokasi di pantai Selatan Jawa, dimana kapal-kapalnya beroperasi di Samudera Hindia yang merupakan jalur migrasi ikan tuna dan sejenisnya. Seperti juga dikatakan oleh Nurani et al. (2007) bahwa salah satu jenis ikan unggulan di perairan Selatan Jawa adalah tuna dan PPN Palabuhanratu mempunyai fasilitas untuk pengembangan perikanan tuna selain PPS Cilacap. Ditambahkan oleh Mertha, I.G.S. et al. bahwa kedekatan Palabuhanratu dengan Muara Baru Jakarta dan Bandara Cengkareng menjadikan waktu transportasi lebih pendek dan biaya semakin kecil bila dibandingkan kalau tuna tujuan ekspor didaratkan di Cilacap. Kondisi tersebut berpeluang terhadap berkembangnya industri perikanan yang berbasis ikan tuna dan sejenisnya karena memiliki nilai ekonomis tinggi dan merupakan komoditas ekspor utama dari sektor perikanan. Menurut Chaidir (2008), bahwa pemasaran tuna terbanyak diarahkan ke industri pengolahan tuna, sesuai dengan permintaan tuna di pasar internasional terutama dalam bentuk tuna loin, steak dan fillet. Proyeksi ikan tuna di PPN Palabuhanratu yang juga menunjukkan peningkatan, dapat berpeluang meningkatkan produktivitas industri pengolahan ikan berbahan baku ikan tuna.

Saat ini di PPN Palabuhanratu belum ada industri pengolahan yang berbahan baku ikan tuna sehingga dapat menjadi salah satu daya tarik berkembangnya industri pengolahan seperti sashimi, pengalengan, fillet dan loin tuna serta nugget ikan. Peningkatan produksi tuna dapat tercapai antara lain melalui peningkatan jumlah unit penangkapan tuna longline dan atau diversifikasi payang serta menangkap ikan dengan bantuan rumpon. Mutu ikan tuna yang ditangkap perlu penanganan yang baik sehingga ikan tersebut dapat menjadi bahan baku industri pengolahan yang berstandar eks- por dan berskala besar. Menurut Bahar (1991) bahwa untuk mendapatkan tuna segar berkualitas baik memerlukan penanganan dan metode processing khusus. Penanganan dan pengolahan tuna di atas kapal sangat menentukan grading kualitas produk akhir. Industri pengolahan ikan berskala besar juga membutuhkan sumber daya pendukung yang besar pula sehingga pelabuhan perlu menyiapkan lahan yang luas, air bersih dan ketersediaan bahan baku kontinyu serta pengolahan limbah skala besar. Dengan ditambahnya kolam pelabuhan 2 yang lebih dalam, kapal tuna longline semakin banyak yang masuk ke PPN Palabuhanratu.

Jenis ikan yang juga memiliki produksi besar dan memiliki nilai ekonomis tinggi adalah ikan cakalang. Industri pengolahan ikan yang menggunakan bahan baku ikan cakalang dapat berupa pemindangan, pembekuan, fillet sampai kepada pengalengan ikan. Pada saat ini ikan cakalang yang didaratkan di PPN Palabuhanratu diolah hanya untuk pemindangan, adapun sebagian lainnya didistribusi untuk dijadikan bahan baku industri pengolahan ikan di Jakarta.

Peningkatan produksi perikanan seharusnya dapat mengembangkan industri olahan misalnya dengan besarnya produksi cakalang seharusnya dapat meningkatkan tingkat produktivitas industri pengolahan ikan yang berbahan baku ikan cakalang, namun saat ini yang ada masih terbatas sebagai bahan baku pemindangan. Jenis industri pengolahan ikan yang dapat dikembangkan dan menggunakan bahan baku ikan cakalang adalah pembekuan, pengalengan, fillet dan loin (Fauziah 2007). Produksi ikan cakalang dapat terealisasai apabila ada peningkatan unit penangkapan dan atau diversifikasi alat tangkap khususnya payang, serta peningkatan pelayanan dari pihak PPN Palabuhanratu terutama dalam penyediaan cold storage dan pabrik es. Selain itu diperlukan peningkatan penanganan ikan saat di kapal, hal ini terkait dengan masih rendahnya mutu hasil tangkapan yang didaratkan. Hal tersebut sesuai dengan pernyataan Kreuzer (1971) bahwa penanganan hasil tangkapan di kapal, merupakan salah satu permasalahan terbesar sehingga mutu ikan tidak bagus lagi ketika didaratkan di pelabuhan. Penurunan mutu ini disebabkan karena terlalu lamanya ikan di palka, pengesan yang kurang atau tidak adanya freezer atau pendingin di palka. Bakteri pembusuk pada ikan akan terhambat perkembangannya apabila hidup pada suhu $0^{\circ} \mathrm{C}$, menurut FAO dalam bukunya Draft Code of Practice for Fresh Fish menunjukkan bahwa ikan kondisinya masih segar untuk 15 hari jika proses penanganannya pada suhu $0^{\circ} \mathrm{C}$, sampai 6 hari jika berada pada suhu $4,40^{\circ} \mathrm{C}$, dan 
kurang dari 3 hari jika pada temperatur $10 \stackrel{\circ}{ } \mathrm{C}$. Maka proses penanganan dengan cepat merendahkan suhu hingga minimum setelah hasil tangkapan diperoleh, menjadi sangat penting. Selanjutnya juga dikatakan oleh Le Ry, 2005 bahwa peraturan Uni Eropa sejak 22 Juli 1991 tentang aktivitas penangkapan ikan, yaitu: Hygiene rules for fisherman on board; [2] Conditions for preservation of fish on board; [3] Conditions for handling on shore; [4] Conditions for processing and packing. Di PPN Palabuhanratu usaha peningkatan tersebut dapat dirangsang melalui penyuluhan atau pembinaan oleh pihak pelabuhan agar memperbaiki penanganan ikan dengan air bersih dan es untuk mempertahankan kualitasnya.

Pada pengolahan pemindangan, mutu bahan baku ikan termasuk rendah contoh pada ikan tongkol. Pilihan ikan bermutu rendah ini karena harganya relatif lebih murah sesuai dengan kemampuan finansial pengolah. Seharusnya walaupun untuk industri pemindangan tetap memperhatikan mutu ikan, hal ini berkaitan dengan kepentingan kesehatan. Pada industri pembekuan dan pengalengan ikan standarisasi mutu bahan baku lebih diperhatikan, terkait pangsa pasar ekspor. Industri pengalengan ikan di PPN Palabuhanratu dapat menggunakan bahan baku ikan tuna, cakalang maupun tongkol. Menurut Tampubolon (1983) bahwa jenis industri pengolahan ikan yang dapat berkembang dan menggunakan bahan baku ikan tongkol adalah pembekuan, pengalengan ikan, fillet dan sashimi. Sama halnya dengan ikan cakalang, peningkatan produksi ikan tongkol di PPN Palabuhanratu sangat dipengaruhi oleh jumlah unit penangkapan payang, sehingga jumlahnya perlu ditingkatkan dan atau diversifikasi untuk pertimbangan efisiensi.

Produksi ikan yang termasuk dominan namun proyeksinya menunjukkan penurunan adalah layur. Penurunan produksi tersebut dapat diantisipasi dengan meningkatkan pelayanan terhadap unit penangkapan pancing ulur agar mau mendaratkan hasil tangkapannya di PPN Palabuhanratu, hal ini terkait dengan tempat pendaratan ikan layur yang tidak hanya di PPN Palabuhanratu melainkan juga berada di luar atau di sekitar pemukiman nelayan itu sendiri. Antisipasi lainnya yang dapat dilakukan yaitu mendatangkan ikan layur dari TPI-TPI yang berada di Teluk Palabuhanratu seperti Cisolok dan Ujung Genteng.

Jenis olahan berbahan baku peperek, jangilus, layaran dan pedang-pedang perlu dipertimbangkan untuk dikembangkan karena jumlahnya yang cenderung meningkat. Jenis industri pengolahan ikan yang dapat berkembang dan berbahan baku ikan peperek adalah surimi
(Junianto 2003). Ikan jangilus saat ini sudah digunakan sebagai bahan baku berbagai industri pengolahan seperti bakso, abon dan kerupuk ikan. Jenis industri pengolahan ikan yang dapat berkembang dan menggunakan bahan baku ikan jangilus adalah pembekuan (Adawiyah 2007). Ikan layaran pada saat ini digunakan sebagai bahan baku pemindangan dan dapat dikembangkan bahan baku pembekuan dan surimi (Junianto 2003). Ikan pedang-pedang masih digunakan sebagai bahan baku industri pengolahan pemindangan namun dapat dikembangkan untuk industri pembekuan (Adawiyah 2007).

Keberlanjutan industri pengolahan ikan di Palabuhanratu dapat dicapai melalui strategi pengembangan yang tepat dengan mengestimasi kondisi dimasa akan datang, terutama agar industri tersebut terkonsentrasi di PPN Palabuhanratu. Menurut Lubis (2007) bahwa di Eropa industri pengolahan ikan terkonsentrasi di lokasi pelabuhan perikanan sebagai contoh Pelabuhan Perikanan Boulogne-sur-Mer-Prancis menjadi pusat pengolahan ikan terbesar di Eropa. Data terakhir tahun 2009 dari pelabuhan perikanan tersebut terdapat sekitar 150 perusahaan industri yang mengolah rata-rata 380.000 ton ikan setiap tahunnya. Sebanyak 3/4 bahan bakumya didatangkan dari negara-negara tetangga. Salah satu faktor penting dalam industri pengolahan ikan adalah ketersediaan bahan baku ikan secara kontinyu. Ketidak cukupan produksi ikan dari suatu pelabuhan dapat diatasi dengan mendatangkan ikan dari daerahdaerah lain di sekitarnya. Terdapat cukup banyak perusahaan pengolahan skala kecil sekitar Palabuhanratu yang telah mengambil bahan bakunya selain dari PPN juga mendatangkan dari daerah-daerah lain seperti Ujung Genteng dan Cisolok terutama apabila produksi pelabuhan menurun akibat pengaruh musim barat dimana nelayan tidak melakukan penangkapan ikan di laut. Berkembangnya industri pengolahan di suatu pelabuhan hendaknya didukung dan perlu penelitian lanjutan terhadap keberadaan fasilitas terkait seperti cold storage, pabrik es dan persediaan air bersih.

\section{KESIMPULAN}

Produksi hasil tangkapan PPN Palabuhanratu dalam menunjang industri pengolahan masih terbatas, hanya beberapa jenis ikan yang hasil proyeksinya menunjukkan peningkatan sampai tahun 1017 yaitu cakalang, tongkol, tuna, peperek, jangilus, layaran dan pedang-pedang, sedangkan untuk jenis ikan yang mengalami penurunan jumlah produksi adalah layur, cucut dan pari. Sebagai alternatif solusi, ikan 
yang jumlahnya cenderung menurun dapat didatangkan dari luar Palabuhanratu diantaranya Cisolok dan Ujung Genteng.

Sesuai dengan kontinuitas dari produksi ikan di PPN Palabuhanratu maka jenis-jenis olahan yang dapat dikembangkan adalah pembekuan (tuna, cakalang, tongkol, jangilus, layaran dan pedang-pedang), pengalengan ikan (cakalang, tuna, dan tongkol), fillet (cakalang, tuna, dan tongkol), loin (tuna dan cakalang), surimi (peperek dan layaran), sashimi (tongkol dan tuna) dan nugget ikan (tuna). Dalam menunjang pengembangan tersebut perlu peningkatan fasilitas pelabuhan seperti persediaan air bersih, cold storage dan pabrik es.

\section{DAFTAR PUSTAKA}

Adawiyah R. 2007. Pengolahan dan Pengawetan Ikan. Jakarta: Bumi Aksara.

Bahar S. 1991. Proses Penanganan dan Pengamatan Mutu Tuna Segar di Pelabuhan Muara Baru. Jakarta. Jurnal Penelitian Perikanan Laut No.60. Jakarta. 65 halaman.

Cabanne C. 1973. Les industries Agricoles et Alimentaires dans la France de l'Ouest. Revue NOROIS No 78 : 328-335.

Chaidir A. 2008. Potensi dan Pemanfaatan Limbah Tulang Pada Pengolahan Tuna di Muara Baru. Jakarta. Craby and Starky. Buletin Pengolahan dan Pemasaran Perikanan Edisi Februari 2008. 22-24.

Fauziah. 2007. Strategi Bisnis Produk Pengolahan Perikanan PT Tri Sejati Tata Food di Jakarta Utara. Skripsi. Bogor: Departemen Sosial Ekonomi Perikanan. Fakultas Perikanan dan IImu Kelautan. Institut Pertanian Bogor.

Yunindari I.I., Dinarwan \& N. Farmayanti. 2006. Perspektif Six Sigma dalam Analisis Manajemen Kualitas; Kasus produksi Fish Fillet di PT Dharma Samudra Fishing In- dustry Jakarta. Bulletin Ekonomi Perikanan Vol. VI No. 3 : 97-107

Junianto. 2003. Teknik Penanganan Ikan. Jakarta. Penebar Swadaya. 118 halaman.

Kreuzer R. 1971. Fish Inspection and Quality Control. England. Fishing News (Books) Limited Ludgate House, 110 Fleet Street London, EC4. 290 halaman.

Le Ry J.M. 2005. Cornouaille Fishing Harbours in France dalam Ernani Lubis dan Anwar Bey Pane: International Seminar Procceding : Dinamic Revitalisation of Java on Promoting the Indonesian Fishery Development. 2007. Program Kajian Kepelabuhanan dan Transportasi Maritim (PK2PTM)-LPPM Institut Pertanian Bogor dan Geolittomer-CNRS de Nantes, Universite de Nantes, France.

Lubis E. 2007. Sistem Transportasi Hasil Tangkapan di dan dari Pelabuhan Perikanan. Bogor. Departemen Pemanfaatan Sumber daya Perikanan, Fakultas Perikanan dan IImu Kelautan. Institut Pertanian Bogor. 5 halaman.

Mahyuddin B. 2007. Pola Pengembangan Pelabuhan perikanan dengan konsep Tryptique Portuaire: Kasus Pelabuhan Perikanan Nusantara Palabuhanratu. Bogor: Disertasi (tidak dipublikasikan). Bogor: Departemen Pemanfaatan Sumber daya Perikanan. Fakultas Perikanan dan IImu Kelautan. Institut Pertanian Bogor.

Mertha I.G.S, M. Nurhuda \& A. Nasrullah. 2006. Perkembangan Perikanan Tuna di Palabuhanratu. Jurnal Penelitian Perikanan Indonesia. ISSN 0853-5884: 117 127.

Nurani T.W, J. Haluan, S. Saad \& E. Lubis. 2007. Model Pengembangan Perikanan di Perairan Selatan Jawa. Bulletin PSP Vol XVI No. 2 : 317-344

Tampubolon M.S. 1983. Tuna dan Perdagangannya. Jakarta: Gaya Baru. 